\section{Salas de cinema: cenários de uma história porto-alegrense}

O presente trabalho é um resumo dos dois primeiros capítulos de um livro sobre as salas de cinema de Porto Alegre - ainda sem título - a ser lançado pela Secretaria Municipal da Cultura, em março de 1999. A pesquisa foi realizada, em conjunto, com a Assessoria de Pesquisa da SMC. A proposta editorial não pretende ser uma pesquisa histórica exaustiva, mas reconstruir a função do Cinema no cenário porto-alegrense. Para troca de informações, escreva para sgastal@plug-in.com.br

\section{Susana Gastal}

Mestre em Artes Visuais - UFRGS.

Professora da FAMECOS/PUCRS
O CINEMA NASCEU em 1895. A imagem a se movimentar na tela é simbólica daquele final de século: a indústria jogava novos produtos no mercado, agora pelo sistema de produção em série. A máquina a vapor permitira a movimentação do trem e do navio: pelas janelas, a paisagem passava mais rápido, quase fora de foco. O mundo movia. O homem, eterno criador de imagens, precisava incorporar esta nova visualidade.

A fotografia, desde meados do século, permitia congelar as imagens no papel. Agora, os irmãos Lumiére, em Paris, libertavam as imagens do suporte material: elas ganhavam o ar, o espaço. Luz e lentes. Movimento. A fugaz passagem pela tela branca. Magia.

O novo século estava quase ali. Um século com pressa, ágil, ansioso por emoções. Era preciso viver muito. Era preciso viver esse agora de

“... uma ordem urbano-industrial, que reinverteu as relações campo-cidade, colocou a urbe como o 'lugar onde as coisas acontecem' e trouxe à cena novos atores sociais, portadores de também novas práticas e idéias. A contrapartida cultural desta ampla gama de transformações materiais e sociais é que se entende por modernidade. E ser moderno, é ser do seu tempo." 1

Sinal dos novos tempos modernos, em 1896 - menos de um ano após sua apresentação ao público parisiense - o novo invento estava no Brasil, projetando as primeiras cenas no Rio de Janeiro e São Paulo.

Logo depois, em 5 de novembro, pouco antes que aquele 96 terminasse, a atividade chegava a Porto Alegre, por iniciativa de Francisco de Paola e Dewison. A primeira 
sessão aconteceu, claro, na Rua da Praia, no $n^{\circ} 349$, endereço da Pharmacia Jouvin.

A partir daí, dois tipos de espaços passaram a ser utilizados para projeções dos cinematógrafos: ao ar-livre - na própria rua ou em praças - ou em locais fechados. Em Porto Alegre, os lugares preferidos eram a Praça de Touros situada na rua da República com rua da Concórdia (José do Patrocínio), o Theatro São Pedro, o Teatro Politeama, o Salão da Bailante e outras casa de diversão onde os exibidores permaneciam enquanto houvesse platéia. O cinema era uma atividade completar e convivia com outras atividades comerciais. Nos teatros, o cinematógrafo fazia parte da programação das companhias de variedades, das companhias de revistas. Estas, provavelmente, deveriam utilizar seu próprio gerador de energia, porque a cidade ainda não possuía luz elétrica.

\section{Inicia ○ século}

Porto Alegre, na virada do século, era uma cidade que enriquecia com o comércio da produção colonial dos alemães instalados em São Leopoldo e Novo Hamburgo. A produção era escoada pelo porto local, aumentando a circulação de mercadorias, de pessoas e capitais, para além das instalações portuárias junto ao Guaíba. Os divertimentos da população eram a música, o teatro, as agremiações e sociedades, e o cinematógrafo, freqüentado não só por adultos, mas também com sessões especiais para crianças.

Em 1908, no dia 20 de maio, José Tours - que representava uma fábrica espanhola de materiais cinematográficos - promove a inauguração do Recreio Ideal, a primeira casa com destinação específica para o cinema, em Porto Alegre. Conforme um jornal da época:

“O salão está muito bem preparado e tem grande número de cadeiras, sendo os trabalhos de cenografia executa- dos pelo conhecido cenógrafo Alfredo Tubino. O aparelho cinematográfico é, sem dúvida, o melhor que até agora veio a esta capital, não se notando nas projeções a mínima trepidação." 2

Localizado na Rua da Praia, junto a praça da Alfândega, o Recreio Ideal acomodava confortavelmente 135 pessoas e apresentava uma programação mais definida, com horário fixos: as sessões aconteciam às 15 e às 16 horas (matinês), e às $18 \mathrm{~h} \mathrm{30min}$ e às 23 horas (soirées). O cenógrafo, Tubino, era o mesmo que pintava as bocas de pano do Theatro São Pedro, e que se tornara muito popular na cidade por seu trabalho na decoração de salões e de carros alegóricos para carnaval.

Outras casas seguem-se ao Recreio Ideal. No mesmo ano abriram as portas outros seis cinemas: Recreio Familiar, Berlim, Rio Branco, Cine Variedades e Smart-Salão, todos situados na Rua da Praia, e o Recreio Moderno, na Demétrio Ribeiro. Sobre o Recreio Moderno a imprensa registrava:

“Com aparelhagem cinematográfica de feitura moderna e engenhosa, possuindo uma coleção de vistas novas, de belos e surpreendentes efeitos. Os espetáculos serão diários, das 7 às 11 horas da noite, e as entradas serão facultadas somente a cavalheiros e famílias." ${ }^{3}$

O Smart-Salão ficava no térreo do Grande Hotel, em frente a praça da Alfândega. Uma curiosidade: seus freqüen-tadores poderiam escolher entre ingressos na primeira ou na segunda classe. Os primeiros, assistiriam o film da maneira tradicional; quem optasse pela segunda classe, sentaria atrás da tela, ou seja, veria as imagens com os movimentos invertidos. Por esta razão, pagaria pelo ingresso metade do valor!

A localização dos primeiros cinemas no Centro de Porto Alegre - e, particularmente na Rua da Praia, junto a praça da Alfândega - irá marcar esse espaço. Ainda 
hoje, ali estão os cinemas Imperial e Guarani, como remanescentes dos cinemas de calçada. No início do século, os cinemas compunham, nesta localização, o contexto social porto-alegrense. As conversas dos amigos, na rua, passaram a fazer parte do cenário local. Antes ou depois do cinema, a passagem pela café ou confeitaria era obrigatória.

Destes pioneiros, o Recreio Ideal foi o que permaneceu por mais tempo em funcionamento, só desaparecendo em 1911/12. Talvez sua sobrevivência até a década seguinte se deva a sua ligação ao grupo Pathé que

“... além de fabricar o cinematógrafo, com a industrialização de suas realidades reconstituídas, seus dramas e comédias longos, passaria a dominar por vinte anos o mundo do cinema, alugando, distribuindo seus filmes internacionalmente a preços módicos." ${ }^{4}$

Se a população entregava-se de corpo e alma aos novos modos de vida burgueses e ao cinema, alguns se preocupavam com a novidade. Como Achylles Porto Alegre, em uma de suas crônicas sobre a cidade:

"O frio é intenso, mas, de instante em instante, ouço vozes femininas e rumores de passos na rua; são famílias que vão para o cinema, porque a 'arte do silêncio' é o hoje a cachaça de toda gente, e a loucura do belo sexo. $\mathrm{O}$ cinema pode se dizer acabou de matar a vida em família, que há muito tempo já vinha perdendo o seu encanto e desaparecendo. (...) A hora em que escrevo, muitos lares estão desertos, porque as salas de cinema estão repletas." ${ }^{5}$

No tocante a investimento, instalar uma sala cinematográfica, antes dos anos dez, supunha um certo arrojo, um certo capital:

"Para instalar uma sala dessas seriam necessários, no mínimo, um equipamento de geração de energia, porque a rede elétrica surgiu em Porto Alegre apenas em 1907. Então, a iluminação das salas teria que ser assumida pelo empresário, com um gerador próprio. Além disso, precisaria ter um equipamento para ventilar - ao menos no verão - como parte da infra-estrutura necessária." ${ }^{6}$

\section{Década de 10: • cinema nã๋ men- tel...}

Na década de dez multiplicam-se as salas e os novos pontos de exibição passam a apresentar características arquitetônicas mais específicas à função cinematográfica. As casas não abandonam, entretanto, a sua condição de teatros, apresentando da óperas às variedades, entre um filme e outro. Um nome se destaca entre os novos empreendedores dos cinemas: Eduardo Hirtz.

Hirtz foi sócio de vários cinemas - Coliseu, Apollo, Talia. A partir de 1911, em associação com Damasceno Ferreira e Cia, participa do maior complexo regional de distribuição, que envolve cinemas em Pelotas, Bagé, Santa Maria, Rio Grande e Rio Pardo. ${ }^{7}$ Além de distribuidor e exibi-dor, ele associa um terceiro e importante papel: o de produtor cinematográfico. Pioneiro na produção local, ele iniciou registrando em película festas familiares e quermesses, e acabou envolvido em projetos bem mais ambiciososo.

Na década de dez surgem como salas exibidoras o Odeon, o Coliseu, o Avenida da rua General Câmara, o Íris - mais tarde Cine Selecto - o Cine-Teatro Apollo, o Colombo, o Guarani, o Petit Cassino - mais tarde Cine-Teatro Rex. As novas casas mostram que nem a guerra - a Primeira Guerra Mundial - atrapalharia a expansão da indústria cinematográfica. O conflito europeu atinge mais profundamente a inci-piente produção local, já que dificulta a importação de filme virgem.

Em 1917, ${ }^{8}$ os jornais já falavam no cinema Rio Branco, do Caminho do Meio, no 
Garibaldi e do primeiro Carlos Gomes, em local diverso do atual. Depois ainda vieram o Talia, o República, o Força e Luz, o Democrata, o Brasil, o Nollet e o Eden, a maioria adaptando prédios já existentes para as novas finalidades, outros investindo em instalações especialmente proje-tadas. ${ }^{9}$ Alguns têm vida curta, permanecendo pouco tempo em atividade. Outros, como o Colombo, sobrevivem até a década de setenta. Quase uma exceção, o Guarani, fechado na década de setenta, troca de endereço e passa a ocupar o mezanino do Imperial, mas, lato sensu, continua abrindo as suas portas para a praça da Alfândega, neste novo final de século.

O pesquisador Cláudio Todeschini nos conta que, no início dessa década, o programa dos cinemas continuaria incluindo pequenos filmes de enredo simples e muitos documentários, também de curta duração. Aos poucos foram introduzidos os programas maiores, com a importação de muitos filmes da Cine, italiana, além de longa-metragens americanos e os franceses da Pathé, uma produtora poderosa na época. O sistema organiza-se e permite que as salas ganhem estrutura, com horários fixos em sessões noturnas e matinês, que obrigaram inclusive a alterações urbanas, como a adequação do horário dos bondes para atender os clientes ao final das sessões.

A Porto Alegre da década de dez possuía 120 mil habitantes.

"Funcionavam então cinco estabelecimentos bancários com elevado giro de capital, 2.294 casas de comércio, 154 fábricas e 149 oficinas. No decênio 1910-1920 iniciou-se a edificação do cais do porto, sendo aterrado um vasto trecho da praia onde novas e importantes ruas comerciais surgiram. O Estado, em próspera situação financeira, levantou o majestoso edifício do Palácio do Governo, que é dos mais belos palácios do Brasil."10

Para Pesavento, isto significa que:

“Progressivamente, consolidava-se uma ordem urbana-industrial, onde a cidade era o centro de irradiação de padrões e valores burgueses, assim como era centro das operações comerciais e financeiras e também o espaço onde se concentravam as fábricas e a massa operária." 11

Aumenta, na cidade, a presença italiana, “havendo um relativo monopólio destes em determinadas atividades como açougues, alfaiatarias, sapatarias, assim como no ramo de diversões públicas: cinemas, restaurantes, cafés, confeitarias (...)."12

O cinema, incentivado ou não pelos italianos, torna-se uma forma de comunicação e de diversão fundamental aquela sociedade, um dos pólos da vida social porto-alegrense. As pessoas buscavam a Rua da Praia como centro de reunião, e os cinemas eram um dos pontos de congraçamento, junto com os cafés e as confeitarias, parcerias indispensáveis no antes ou no depois do assistir ao film, para conversar e comentar o que fora visto na tela.

As salas de espera dos cinemas são outros locais de socialização. As pessoas se reuniam ali sem pressa - afinal, era preciso ver e ser visto - numa atmosfera cosmopolita. Lia-se Verlaine, Mallarmé, Baudelaire e, dizem os maldosos, muitos olhavam o Guaíba imaginando-se frente ao Sena...

O star-system já projetava toda uma hierarquia entre as grandes estrelas das telas, e era em torno disso que giravam muitas das discussões. No topo do star-system estavam as divas.

"Os que lembram, sempre fazem a mesma ressalva: eram lindas na tela, mas levavam uma eternidade para atravessar uma sala, sempre envoltas em plumas e peles e trajando longos vestidos. Apesar de os filmes serem projetados em uma velocidade mais rápida do que os atuais - que giram a 24 quadros por segundo nos projetores, simulando uma perfeita ilusão de realidade - as divas italianas arrasta- 
vam-se pelos recamados cenários art déco das produções da época. Eleonora Duse, Pina Menichelli, Lyda Borelli e Rina Ligouro são algumas estrelas do cinema italiano que precederam as stars hollywoodianas, popularizando o termo." 13

A influência do cinema a marcar comportamentos aparece num fato narrado no livro de memórias de José De Francesco, como acontecido em 1918. No episódio, uma senhora entra na Confeitaria Central, na Rua Praia, senta-se e coloca sobre mesa uma fina cigarreira. Toma um cigarro e começa a fumá-lo. O garçom vem alertála que "nesta casa, senhoras não fumam". A freguesa protesta e já começa a causar tumulto. Ofendida, brada: "Nos Estados Unidos fuma-se, casa-se quantas vezes se quer".

O proprietário, a esta altura já envolvido no imbroglio, pergunta se ela já estivera nos Estados Unidos. "Ela, convicta retruca: Não! Mas os filmes no-lo mostram, não é preciso ir lá, pois o cinema não mente..."14

Embora gerando muitas palavras e conversas entre os seus aficionados, os filmes ainda eram mudos. Um ou dois músicos - ou até pequenas orquestras - encarregavam-se da tarefa de construir o clima sonoro; os músicos deveriam eletrizar as passagens tensas ou construir a atmosfera romântica para as cenas de paixão.

Foram importantíssimos nas suas funções e a atividade passou a significar um importante mercado de trabalho para os instrumen-tistas. Casas pequenas, como o Recreio Ideal, possuíam pianista, às vezes acompanhado por um violinista.

Casa maiores, como o Odeon, tinham orquestra composta por um grande número de "professores", palavra utilizada na época para reforçar o gabarito dos profissionais.

Para alguns filmes havia uma partitura própria, que os acompanhava; em outros casos, os músicos improvisavam. Não raro, as partituras se perdiam no circuito do filme, e a responsabilidade da sonorização voltava a ser entregue aos instrumentistas. Os profissionais sabiam do que a platéia gostava e cuidavam de atendê-la, provocando lágrimas ou risos.

“Era um prazer ouvir as orquestras. Os professores perdiam horas selecionando os repertórios, de acordo com os argumentos dos filmes. Recordome que, quando foi exibido o filme de Francesca Bertini, Assunta Spina, encaixaram a partitura 'Sordatto Innamo-rato', cujo trecho, embora o filme fosse mudo, figurava no enredo como se 'Assunta' o cantasse - Oi vitta, oi vitta mia, oi cuore de chuesto core, sei stato oprimo amore, oprimo e l'último sarai per me." 15

Outra novidade da década de dez, é as salas de exibição deixarem de ser exclusividade da Rua da Praia. Há o Coliseu "lá" na Voluntários da Pátria e o República "lá" na Sete de Setembro, quase esquina com General Canabarro; o primeiro Avenida, na rua General Câmara, ao lado da Confeitaria Colombo; o Força e Luz na avenida Eduardo (depois avenida Presidente Roose-velt); o Democrata na São Pedro; o Brasil e o Nollet na rua da Margem (hoje João Alfredo). Mesmo bairros distantes, na Zona Sul, ganharam cinemas.

$\mathrm{Na}$ Tristeza, surge o Maravalha em 1917.

"Seu Dario Gontrã trazia os filmes da cidade, seu Socrates Gandolffi, proprietário do cinema, passava-os e dona Regina, sua esposa, cobravas as entradas - trezentos réis. A máquina funcionava com arco voltaico, espalhando chispas para todos os lados. Seu Sócrates tinha como auxiliar o Sr. Josino Silva, que se encarregava de tudo na sua ausência para as caçadas."16

Se o instalar uma casa exibidora em frente a praça da Alfândega era um risco, afastar-se um pouco desta quadra seria 


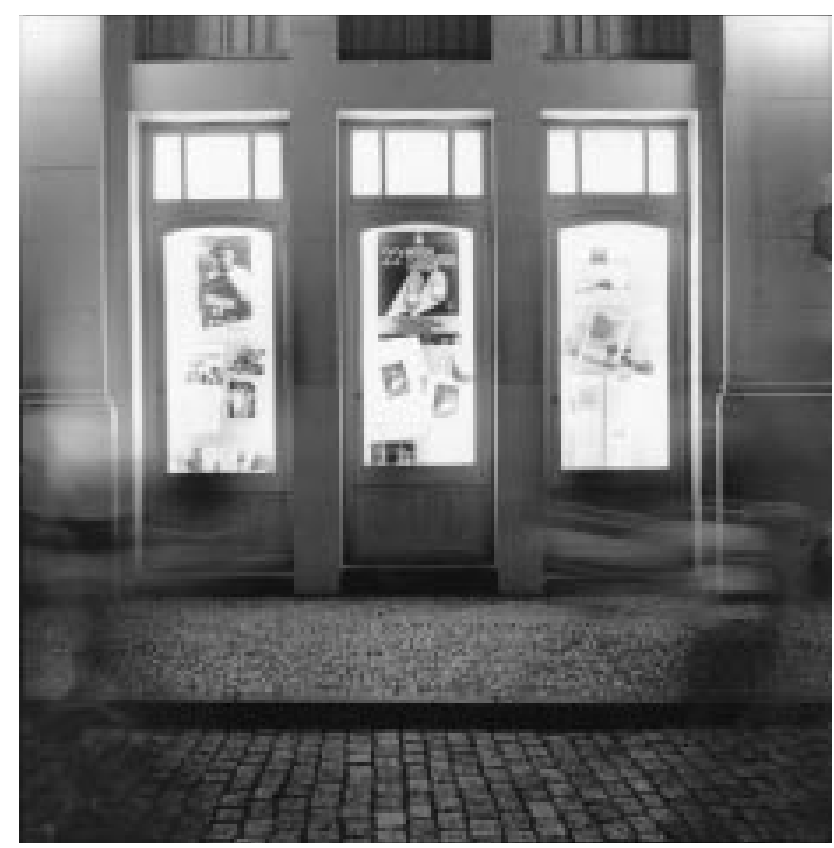

FOTO 1

Desde a primeira sessão, em 1896, a Rua da Praia caracterizouse por sediar as principais salas exibidoras de Porto Alegre. Hoje, os cinemas da Casa de Cultura Mário Quintana mantém a tradição. (Foto Eduardo Aigner, 1998)

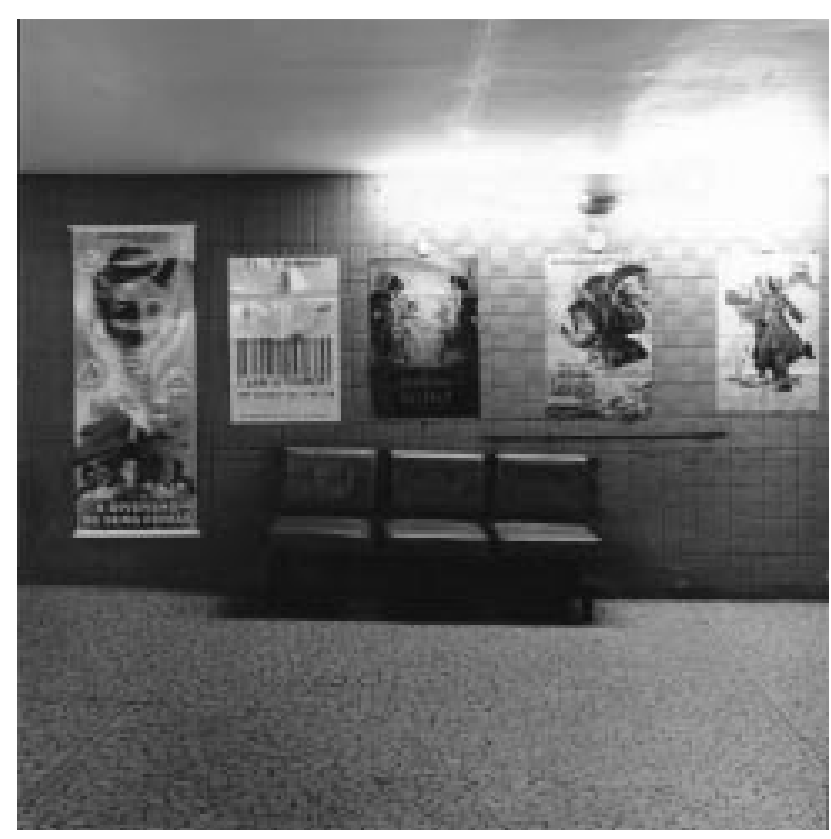

FOTO 3

As salas de espera dos cinemas sempre foram ponto-de-encontro. As conversas dos cinéfilos fizeram delas parte do cenário local. Antes ou depois do cinema, a passagem pela café ou confeitaria era também obrigatória. (Foto Eduardo Aigner, 1998)

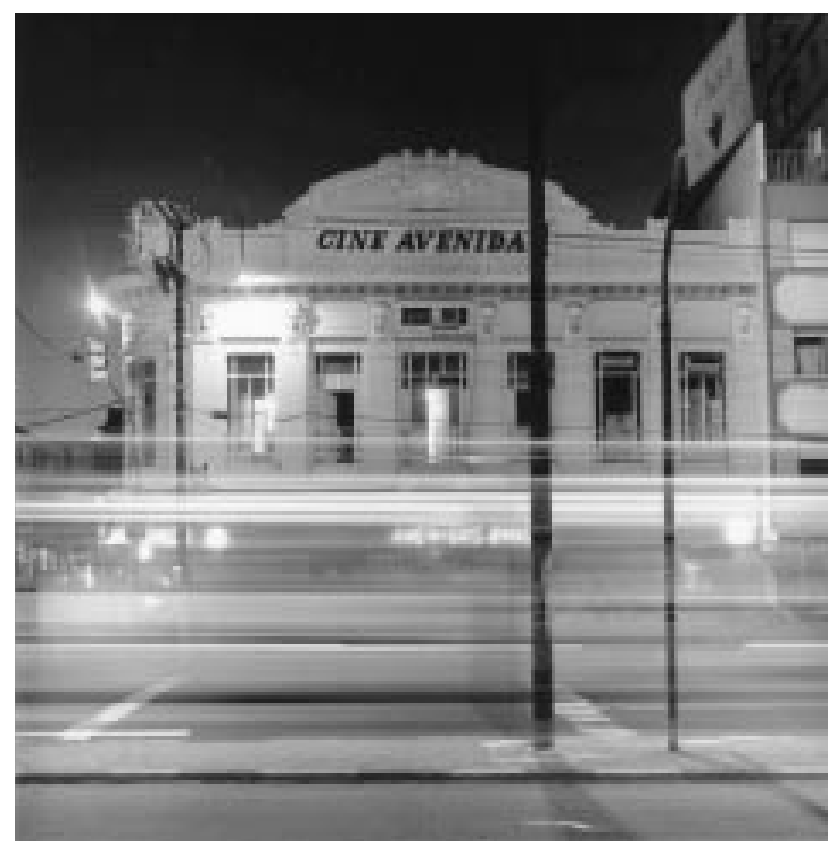

FOTO 2

0 primeiro Avenida, na década de dez, ficava na rua General Câmara, ao lado da Confeitaria Colombo. $O$ Avenida da João Pessoa funcionou entre 1923 e 1996. 0 prédio da foto foi inaugurada em 1929. (Foto Eduardo Aigner, 1998)

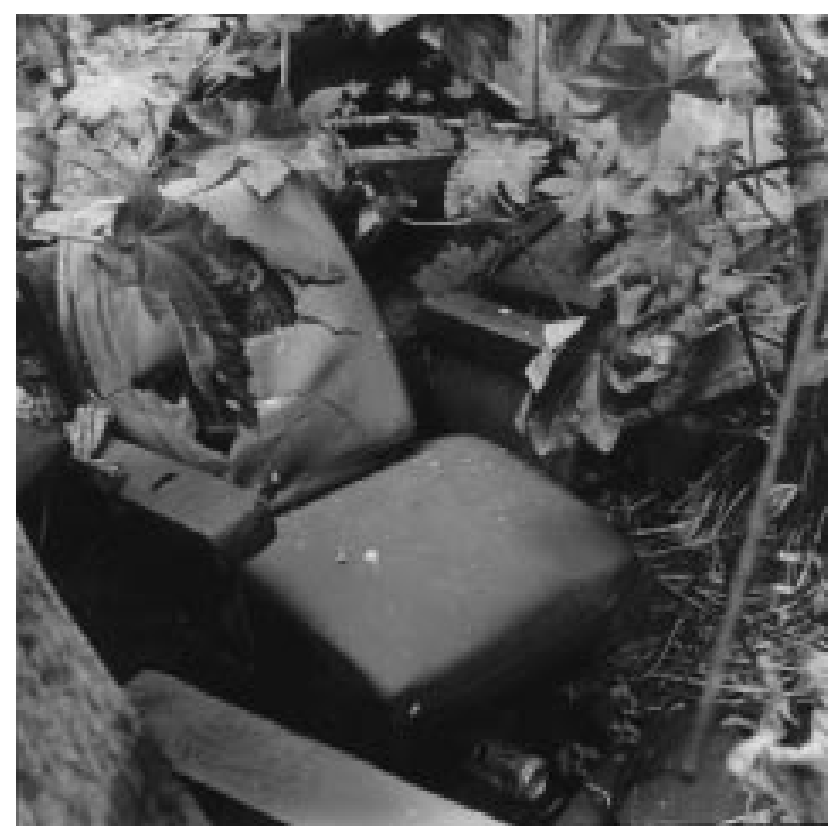

FOTO 4

Os anos 80/90 assistiram a decadência dos cinemas de calçadas e o início da era dos shoppings. Do Recreio Ideal, a primeira casa de cinema porto-alegrense, inaugurada em 1908, na Rua da Praia, nada restou. (Foto Eduardo Aigner, 1998) 
mais temerário aos empresários locais. O República, por exemplo, nasceu da adaptação de três prédios, obra realizada por um sócio do cine Talia, chamado Carlos Faidrich, num terreno que ia da Rua da Praia até a 7 de Setembro, próximo ao quartel da Brigada Militar. Segundo De Francesco, o República foi montado

“... tendo todo conforto para o público. Com uma ordem de galerias, excelente serviço como nenhum cinema da época: pintei o pano de boca. Nesse teatro estreou a Cia de Comédias Silva Filho (...). Lástima, o povo daquela época não saía do centro, e o teatro teve vida efêmera." 17

\section{Coliseu}

Na esquina da Voluntários da Pátria com Pinto Bandeira, em frente a praça Osvaldo Cruz, os irmãos Petrelli inauguraram, em dezembro de 1910, o primeiro prédio do Teatro Coliseu,

“... um grande e belo barracão, fantasiosamente enfeitado - no mesmo local, segundo o historiador Olynto Sanmartin, em que funcionava o Teatro. Criado para Politeama a programação da nova casa logo mesclava a exibição de espetáculo ao vivo com a do cinematógrafo, funcionando como teatro, logo a casa era conhecida como cineteatro, com seus 1.410 lugares." 18

O mesmo pesquisador ainda explica que o sucesso das salas de projeção na década de dez, teria

“... induzido os irmão Petrelli a construir, no mesmo local, um novo prédio para o Teatro Coliseu, bem maior, de imponente arquitetura eclética, no estilo de construções buenairenses, e características do final do século XIX." ${ }^{19}$
Como era a nova casa? Bem, ela nasceu da transformação externa do prédio, recebendo fachada em alvenaria e, na parte interna, novos pisos, para abrigar confortavelmente três mil pessoas. $\mathrm{O}$ espectador poderia escolher entre sentar na platéia, nas frisas - camarotes quase ao nível da platéia - ou em alguma das três galerias. Os ingressos para os camarotes - com direito a cinco entradas - custavam 6\$000; as poltronas numeradas, $1 \$ 500$; platéia, $1 \$ 000$; arquibancada numerada $\$ 700$; e as galerias, $\$ 500{ }^{20}$

O espetáculo começava às $20 \mathrm{~h} 30 \mathrm{~min}$, com garantia de bondes à saída da sessão para o Menino Deus, Escola de Guerra (Gasômetro), Teresópolis, Glória, São João, Navegantes e Independência.

Segundo Archymedes Fortini, o Coliseu nasceu da associação dos Irmãos Petrelli com os Irmãos Hirtz - já nossos conhecidos como proprietários do Recreio Ideal. Os cartazes de propaganda da casa faziam questão de salientar como "Professor da Orquestra, sr. Pedro Ribeiro Alvares" ${ }^{21}$

O Coliseu,

“... tornou-se popular e grãfino. Companhias cariocas traziam cantores do momento, com as figurantes que chamavam 'girls' e iam mostrando cada vez mais as rotundas formas. Seus luminosos pisca-piscavam os nomes de Jayme Costa, Aisa Garrido, Dulcina de Moraes, Abel Pera, Mesquitinha, Grande Otelo, Procópio Ferreira, Dercy Gonçalves." ${ }^{22}$

No dia 6 de setembro de 1928, em sua página 10, o Correio do Povo registrava:

“Estão de parabéns os amantes da scena muda; o simpático e confortável teatro Coliseu vai passar a exibir, em primeira mão, os mais notáveis filmes que vêem ao Brasil. Breve inauguração."

Dias depois, a sessão "Mundo Cinematográfico" do mesmo jornal, voltava ao 
assunto revelando que o filme Casanova seria a película com a qual a AGC iniciaria as exibições, ainda no mês de setembro.

Outro que possui boas recordações do Coliseu é o pintor Carlos Scliar:

"Me lembro que o meu pai (...) costumava ir no cinema Coliseu, que ficava ali na Voluntários da Pátria. Era um cinema quase que especializado em cinema alemão. (...) Estou falando da década de vinte a trinta: eu vi os clássicos do cinema alemão, no Coliseu, com meu pai. Como é que um garoto de sete, oito anos, iria ao cinema sozinho? Eu, morando lá no Partenon, vir aqui na rua Voluntários da Pátria ver cinema! Eu vinha com meu pai. Eu me lembro de filme do Fritz Lang. O cinema alemão daquela época era muito bom - período especialíssimo do cinema expressionista. Eu vi filmes, levado pelo meu pai, e aquilo fez a minha cabeça. São filme que eu nunca mais esqueci. Não posso dizer que eu me lembre de todo filme, mas de pedaços de filme sim, e aquilo me marcou demais." 23

Antes de cerrar suas portas, o Coliseu alternava em sua programação filmes " $B$ " e grupos teatrais também de segunda linha.

Fechou definitivamente em 23 de setembro de 1956. Antes de cerrar suas portas, após cinqüenta anos de funcionamento, houve uma tentativa de campanha em prol da restauração do prédio, autorização negada pela prefeitura porque o Plano Diretor previa, para o local, um corte de onze metros: eram as obras de prolongamento da avenida Farrapos.

Em sua edição de 15 de setembro de 1957, o jornal A Hora anunciava que, no lugar do Coliseu, seria construído um prédio de 27 andares - "o maior de Porto Alegre" com onze lojas no térreo. Na promessa, a inclusão na construção do Teatro Petrelli, uma homenagem aos primeiros proprietários do Coliseu.

\section{O mesmo jornal A Hora registrou:}

"Quando assim acontecer [e o Coliseu cerrar suas portas], então nada mais restará do que a saudade de noitadas alegres que davam ao porto-alegrense um repertório teatral a altura da gente dos grandes centros. Quanto a última encenação, esta é melhor esquecê-la."

\section{Guarani}

O Guarani foi construído em 1913, com fachada projetada por Theo Wiedersphan, arquiteto responsável pelos principais prédios de Porto Alegre nas décadas de dez e de vinte. A sala de exibição tinha camarote no primeiro andar, balcões ou galerias no segundo, e a geral no terceiro andar, a exemplo de outras casa da cidade, ainda uma reminiscência dos cine-teatros inspirados no Scala de Milão.

Agora, as sala eram cada vez mais projetadas com uma arquitetura visando também a nova forma de espetáculo, embora nos seus palcos desfilassem espetáculos de óperas, operetas, de revistas e de companhias dramáticas. ${ }^{24}$

Todeschini utiliza a palavra "eloqüente" para denominar esta arquitetura, talvez um termo adequado para caracterizar a estética construtiva da época. Ainda segundo o pesquisador,

“... pelos nomes das salas de espetáculos se vê que havia uma influência dos grandes centros. Era o Roxy, era o Coliseu. Muitas salas eram americanas, nova iorquinas, a exemplo de Rio e São Paulo, e acabavam utilizando, aqui, o mesmo tipo de denominação e arquitetura: fachadas com incidência neo-clássicas, algumas ecléticas, algumas até barrocos - como no caso do Guarani. Ali tinha certamente uma atmosfera que se criava em torno do cinema, havia um certo mistério, que de certa maneira permanece em torno 
dos cultores e atores do cinema. Tudo isso exigia também coerentemente uma grande eloqüência arquitetônica compatível." 25

Simpático em relação ao Guarani, é que seu nome foi escolhido por um concurso popular, patrocinado pelo Correio do Povo.

Nos anos quarenta, o Guarani sofreu uma reforma - visando adequá-lo melhor às condições de cinema - e foi reinau-gurado com o nome de Cinema Rio. A nova denominação durou até os anos cinqüenta, quando outra reforma modernizou as cadeiras e eliminou uma parte do mezanino, e a denominação voltou a ser Guarani. $\mathrm{O}$ proprietário do cinema era Darcy Bitencourt, desde a época do Cinema Rio. Além do Guarani, Bitencourt era proprietário, no período, do Rex, Roxy, Talia, América, e Coliseu.

\section{Odeon}

O Odeon foi inaugurado em 1910, num ponto da Rua da Praia que sucumbiu com a abertura da avenida Borges de Medeiros. A inauguração aconteceu na tarde do dia 6 de janeiro, numa sessão para convidados, que brindaram ao evento com champanha. A noite, a casa abriu para o público em geral. $O$ jornal, no dia seguinte, relatava:

“O Odeon está magnificamente instalado, em vasto e elegante salão guarnecido de grande número de ventiladores, bem iluminado e bem mobiliado, com 170 confortáveis poltronas, para espectadores de primeira classe, e 100 cadeiras de palhinha para os de segunda." 26

$\mathrm{Na}$ segunda classe, o ingresso era significativamente mais barato. Independente do local, todos desfrutavam da selecionada orquestra de dez ou doze "professores" que sonorizava as sessões, "eletrizando as pas- sagens ou dando dimensão as imagens", ${ }^{28}$ sob direção do professor Angelo Tagnin.

O Odeon era conhecido na cidade porque, após às onze horas, apresentava sessões só para homens, "certamente com os na época denominados 'fortes' ou 'livres', com 'nus artísticos' ou temas científicos sobre doenças venéreas." 28

\section{Outras casas}

Abrindo suas portas em $1^{0}$ de abril de 1914, o Apollo, com dois mil lugares, já nasceu voltado para o cinema, mas também ele tinha um palco. A casa não teria camarote ou balcões, apenas o mezanino. Situado na avenida Independência, onde hoje está o edifício Santa Tecla, o cinema era nova iniciativa do dinâmico Eduardo Hirtz.

A nova sala abre

“... com um projetor, protótipo inteiramente fabricado aqui, pela firma Hirtz e Rehn, que levou o nome de Brasil, conseguindo 'a abolição completa da trepidação nas projeções e fixidez absoluta das imagens', pioneirismo que os projetores europeus até então não haviam conseguido." ${ }^{29}$

O cinema Apollo, segundo o De Roco - antigo proprietário do Cinema Gioconda - "era o maior cinema (...) do Brasil, também porque aquilo era um enorme de um galpão, onde cabiam três mil pessoas lá dentro. E ele enchia." ${ }^{30}$

O Íris situava-se na Rua da Praia, onde por muito tempo esteve a casa Sloper - loja que, nos anos noventa, virou casa de bingo - "com uma saída para a rua Uruguai. Sua tela era uma pintura branca na parede." ${ }^{31}$

Segundo o pesquisador Todeschini, outro cinema da época, o Petit Cassino, possuía características semelhantes ao Guarani, mas sua fachada era neoclássica. De Francesco relata que em torno de 1918 - o Petit Cassino já fechado como cinema - o pintor paulista Torquato Bassi realizou uma expo- 
sição na sua sala de espera, mostra que teria agradado ou público e resultado em ótimas vendas. Em 1937 transforma-se em Cine Teatro Rex, num "simulacro da cultura francesa para a americana". ${ }^{32}$

O primeiro Carlos Gomes ficava na Rua da Praia, no mesmo local onde fora o Recreio Ideal. Este local, lá por 1918, não parecia gozar de muito boa reputação. Sobre ele De Francesco assim se refere:

“(...) de teatro somente tinha o nome, pois era uma espécie de cabaret, onde exploravam o jogo, e cujo gerente era o Oliveira, um moreno que era compositor. Mandou-me pintar vários cenários, assim passei vário dias, porém o dinheiro quase não via (...)." 33

Até os anos dez, a aventura que acontece nas telas é quase a mesma vivida por aqueles que se aventuravam a instalar uma casa exibidora de filmes: sem um mercado constituído, ainda havia muito espaço para a livre iniciativa dos sonhadores. Época de imagens, quando o cinema ainda não falava. E quem a viveu, não esquece:

"Sim, claro, eu peguei o cinema mudo. Então a gente ia, ficava na frente, era uma farra porque a gente queria entrar para ajudar o mocinho, teve gente que queria pular para cima do cenário para briga, porque o mocinho era o Tom Mix, Quik Jones, aquela turma conhecida, tudo era mocinho. Em baixo, na ribalta era o pianista, que conforme a cena, se era cavalgada ou de mais força, ele aumentava. (...) e isso entusiasmava a garotada. Tinha uns meio maluco que queriam pular para lá porque a mocinha se debatia com o bandido, aí vinha o Tom Mix, o Rintintim e pegava na calça do Rose, então todo o cinema aplaudia, viva, viva, viva... Eram coisas da época, imagina, fazer isso hoje é um escândalo ou ao menos um ridículo." 34

\section{Notas}

1 PESAVENTO, 1992:8.

2 TODESCHINI, 1995: 14.

3 Idem, p. 15.

4 Idem, p. 15.

5 PORTO ALGRE, A. apud Pesavento 1992:15.

6 Cláudio Todeschini, em entrevista aos pesquisadores.

7 PFELL, 1995: 20.

8 COSTA FRANCO, 1992:117.

9 Cf. VIEIRA, JL et al. In: "Cinemas da Metro e a dominação ideológica". Filme Cultura, n 47, ag/86 p. 59: "O cinema historicamente levou um certo tempo para constituir uma arquitetura específica, com superfícies, planos e volumes próprios. Das fotografias animadas ao cinema como experiência estética, o espaço que acolheu essas imagens em movimento passou das pequenas salas improvisadas do final do século para o requinte dos Roxys e Capitols disseminados pelo mundo inteiro".

10 FORTINI, 1962: 109.

11 PESAVENTO, s/d: 42.

12 Constantino apud CORREIA, 1994:31.

13 BECKER, Tuio, Zero Hora, 4-12-95. Becker ainda destaca: "Em oposição aos dramas com as divas, o cinema italiano desenvolveu uma série de filmes colossais, de grandes espetáculos, que marcaram o advento do longa-metragem, Quo vadis?, de Enrico Guazzoni (1913) e Cabiria, de Giovani Pastrone (1914) levaram meses para serem filmados e exigiram um capital colossal. Serviram de inspiração para que W. Griffith realizasse Intolerância (1916)".

14 FRANCESCO, 196: 52.

15 Idem 1962:92.

16 PELLIN, Roberto. Revelando a Tristeza, s/d, e/editora. 
17 FRANCESCO, 1962: 59.

18 TODESCHINI, no jornal 0 Continente

19 Idem ibdem

20 FORTINI, 1966:119

21 Idem, p.117.

22 Todeschini, no jornal 0 Continente.

23 Carlos SCLIAR, em entrevista a autora em agosto de 1998.

24 VIEIRA, JL et al. "Cinemas da Metro e a dominação ideológica. Filme Cultura, n 47, ag/86 p. 59-61. Os autores escrevem que: "A uma estandartização da linguagem do filme corresponde também uma estandartização da linguagem da sala. Os cinemas da MGM, embora projetados por arquitetos no Brasil (ainda que estrangeiros, vivendo no Brasil), são completamente supervisionados por técnicos americanos. Em todos os níveis, a Metro buscou definir junto ao público uma forma específica de consumir filmes, identificada com sua própria marca. (...) Cedric Gibbons, principal diretor de arte da companhia, já havia definido e caracterizado como o visual da Metro: rico, aveludado, de sonhos". Este não foi exatamente o caso do Guarani, que ainda segui mais as estruturas arquitetônica do teatro, do que do cinema.

25 TODESCHINI, em entrevista aos pesquisadores.

26 Apud TODESCHINI, 1995:15.

27 TODESCHINI, em entrevista aos pesquisadores.

28 TODESCHINI, no jornal 0 Continente, p. 13.

29 PFEIL, 1995:20.

30 De Roco, em entrevista aos pesquisadores

31 TODESCHINI no jornal O Continente, p. 12.

32 Idem ibdem.

33 De FRANCESCO, 1962:57

34 De Roco, em entrevista aos pesquisadores.

\section{Referências}

BECKER, Tuio (org). Cinema no Rio Grande do Sul. Porto Alegre: Unidade Editorial SMC, 1995.

CANEZ, Ana Paula. Fernando Corona e os caminhos da arquitetura moderna em Porto Alegre. Porto Alegre: Unidade Editorial SMC, 1998.

CORREIA, Silvio M.S. Sexualidade e poder na Belle Époque de Porto Alegre. Santa Cruz do Sul: Unisc, 1994.

COSTA FRANCO, Sérgio. Porto Alegre: guia histórico. Porto Alegre: Ufrgs/PMPA, 1992.

DOBERSTEIN, A. Estatuária e ideologia. Porto Alegre: SMC, 1992.

FERREIRA, Athos Damaceno. Artes plásticas no Rio Grande do Sul. Porto Alegre: Globo, 1971.

FRANCESCO, José de. Reminiscências de um artista. Porto Alegre: s/editora, 1961.

FORTINI, Archimedes. Porto Alegre através dos tempos. Porto Alegre: Divisão de Cultura, 1962.

FORTINI, Archimedes. Histórias da nossa história. Porto Alegre: Grafitel, 1966.

MARONEZE, L.A.G. "Espaços de sociabilidade e memória: a vida pública porto-alegrense 1890-1930". Caderno Porto\&Virrula - Teses e Dissertações 1, Porto Alegre: Unidade Editorial/SMC, 1996.

MORENO, Antonio. Cinema Brasileiro: história e relações com 0 Estado. S/local: Editora UFG, 1994.

PESAVENTO, Sandra J. A burguesia gaúcha: dominação do capital e disciplina do trabalho. Porto Alegre: Mercado Aberto, 1988.

PESAVENTO, Sandra J. (coord.) Memória Porto Alegre - espaços e vivências. Porto Alegre: Editora da Universidade/PMPA, $\mathrm{s} / \mathrm{d}$.

PESAVENTO, Sandra J. O espetáculo da Rua. Porto Alegre: Ufrgs/PMPA, 1992. 
PFEIL, A. Jesus. "Cinematógrafo e o cinema dos pioneiros". In: Caderno Porto\&Virgula - Cinema no Rio Grande do Sul. Porto Alegre: Unidade Editorial/SMC, 1995.

TODESCHINI, Cláudio. "O cinematógrafo numa ilha de civilização". In: Caderno Porto \& Vírgula - Cinema no Rio Grande do Sul. Porto Alegre: Unidade Editorial/SMC, 1995.

VIEIRA, J.L. et al. "Cinemas cariocas: da Ouvidor à Cinelândia". Filme Cultura n 47 , agosto 1986. 